\title{
The Investment Strategy of Taiwan Futures Market after Quantitative Easing Monetary Policy
}

\author{
Yu-Wei Lan \\ Department of Banking and Finance, Takming University of Science and Technology \\ Dan Lin \\ Department of Banking and Finance, Takming University of Science and Technology
}

Lu Lin

Department of Public Finance and Taxation, Takming University of Science and Technology

\begin{abstract}
After the financial crisis in 2008, US Federal Reserve adopted quantitative easing monetary policy to boost the US economy. However, the hot money made tremendous shocks in financial markets. After 2015, the US job market stabilized and the Fed ended the $Q E$ and started raising interest rates. The aim of this study is to show that institutional investors affect TAIEX futures through MSCI Taiwan Index Futures, and consequently affect Taiwan 50 ETF. This study incorporates the price spread of TAIEX futures and MSCI Taiwan Index Futures in the model to conduct backtesting using program trading. This can help us determine if the mean reversion model is better than the contrarian model and the momentum model. The results show that the mean reversion model has higher profits and stabilities than the contrarian and momentum models. The results suggest that incorporating the price spread of TAIEX futures and MSCI Taiwan Index Futures and utilizing the mean reversion property of behavioral finance can enhance trading performance.
\end{abstract}

Keywords: Mean Reversion; Program Trading; Granger Casualty Test; Efficient Market; Quantitative Easing

\section{INTRODUCTION}

After the 2008 financial crisis, the US Federal interest rate was near zero. This suggested that the traditional monetary policy was no longer useful in solving economic problems. As a result, the US Federal Reserve (thereafter, the Fed) started a series of quantitative easing (QE) monetary policy. The first QE was executed between March 2009 and March 2010. The size of QE1 was about US\$1.725 trillion; that was about US $\$ 100$ billion on average every month. The QE2 was executed between November 2010 and June 2011. QE2 had the size of around US\$600 billion, which had mainly been used to buy long-term Treasury bonds. The average purchase amount every month was about $\$ 75$ billion. The QE3 was executed in September 2012. In September, the Fed bought US $\$ 23$ billion Treasury securities and from October, the Fed bought US $\$ 40$ billion per month. From January 2013, the Fed increased the purchase amount to US $\$ 85$ billion. Essentially, the money was printed to buy mortgage-backed securities (MBS), Treasury long-term notes, US government bonds and agency MBS. The purpose was to raise the price of long-term US bonds and lower interest rates. This could also lower the mortgage interest rates and provide support for the housing market.

As US dollar is the reserve currency around the world and many major commodities are priced in US dollars. More than $\$ 2000$ billion base money was injected into the domestic market after 
QE. At such a low interest rate environment, the US dollar fell dramatically. The US Dollar Index fell from a high of 88.8 on 12 June 2010 to a history low of 72.89 . In actual fact, by printing more money, QE was used to dilute debt and transfer risk. The high liquidity made the international capital flow even more uncertain, which led to asset bubbles and financial risks in other countries. As the US job market improved, the Fed started to reduce the size of QE from January 2014. The bond purchasing amount reduced by US\$10 billion to US $\$ 75$ billion. The QE was ended in October 2014 and the Fed raised interest rate in December 2015. The US Dollar Index rose to a high of 100.6 on 3 December 2015. The liquidity around the world started to contract and hot money flew out of emerging markets, bringing dramatic impacts to these countries' financial markets.

As the trade dependence between Taiwan and the US is quite high, a shallow market like Taiwan cannot avoid being affected by QE. As the Taiwan government aimed to globalize and internationalize the financial market, foreign investors were allowed to invest in spot and futures markets. In 1996, the government revised the regulation on securities investment and foreign exchange settlement by overseas Chinese and foreign investors. Foreign institutional investors and individual investors were also allowed to directly invest in the domestic securities market. Before 1996, although foreign investors were allowed to invest in Taiwan, the trading volume by foreign investors was very low as foreign investors typically trade in both spot and futures market for hedging purposes. Only until 1998, the government cooperated with the CME and SIMEX to release new Taiwan index futures and later on created the local Taiwan index futures (TAIEX futures). In May 2000, the Treasury Department reduced the transaction tax of local futures from $0.1 \%$ to $0.05 \%$. Thereafter, the fluctuations of Taiwan stock market were affected by Taiwan Stock Exchange, Taiwan Futures Exchange and SIMEX.

TAIEX futures is a financial futures contract which uses Taiwan stock market index as the underlying asset. The quotes of TAIEX futures and Singapore's MSCI index futures have a stable cointegration relationship. The spot and futures markets have long-term stable equilibrium relationship and the Taiwan index futures have good price discovery function of the spot market price. As the global financial markets keep developing, capital can freely flow from one market to the other market and the information can spread efficiently. The foreign exchange market, stock market and futures market become more closely tied. The price in one market can influence the price in the other markets. For example, on 12 June 2010, the US Dollar Index was at a history high of 88.8. Meanwhile, the Taiwan stock index was at 7300 . When the US Dollar Index fell to a history low of 72.89 on 2 May 2011, the Taiwan stock index rose to 9000. Then, when the US Dollar Index rose back to a high of 84.83 on 13 July 2013, the Taiwan stock index dropped to 8100 . Facing with such a volatile market, individual investors who lack for accurate information were likely to run away from the market. In actual fact, the trading by individual investors had decreased to about 50\%. Therefore, how to use behavioral finance to help individual investors trade in the financial market is worth investigating. It can also help the stock market to reflect its true price more accurately and the Taiwan stock market is more likely to transform from a shallow market to become a mature stable market.

Therefore, this study proposes investment strategies from behavioral finance and stock market index futures perspectives. The organization of this paper is as follows. Section 2 provides literature review. Section 3 explains the research methods, including event studies, Granger causality model, and program trading estimation methods. Section 4 discusses the data source. Section 5 provides empirical results and analyses. The final section then gives a conclusion. 


\section{LITERATURE REVIEW}

How to make profits in stock markets has been a hot issue among the financial markets. Fama (1965) proposes that the trend in stock prices is random. If stock price fluctuations have incorporated all expectations and information of market participants, then the stock price is not predictable. This is a market efficiency problem. Fama (1970) thus formally proposes an efficient market hypothesis (EMH). His idea was consistent with the main stream of economic thinking at that time. According to Fama $(1965,1970)$, the efficiency of a market can be classified into: (1) weak form efficient market, whereby all past information has been reflected in stock prices; (2) semi-strong form efficient market, whereby all public and relevant information about the future prospects of the companies have been reflected in stock prices; and (3) strong form efficient market, whereby all information related to the company is reflected in the price. However, after 1980's, more and more evidence shows anomalies in markets, such as momentum effect and reversal effect. The latter anomaly exists because investors believe that there exists mean reversion effect in stock returns. That is, stocks that rise in the short and medium term will fall, and falling stocks will eventually rise. Therefore, investors can adopt contrarian strategy to increase trading efficiency.

Basu (1977) examines the relationship between P/E ratio and investment returns of NYSE listed companies between 1957 and 1971 and finds that firms in the low P/E ratio group has average yearly return of $16.3 \%$, which is much higher than firms in the high $\mathrm{P} / \mathrm{E}$ ratio group. The latter has average yearly return of $9.3 \%$. The results show that contrarian strategy can lead to trading profits. Shiller (1979) also finds that the overreaction in opportunistic asset prices contradicts with the concept of an efficient market. Poterba and Summers (1988) use the variance ratio test to examine the market returns of the US market between 1871 and 1986 and market returns of seventeen other countries between 1957 and 1985. They find positive correlations in stock returns in the short term but negative autocorrelation in the long term. Based on the price changes data of NYSE listed companies between 1926 and 1985, Fama and French (1988) find negative autocorrelation in 3 5 year stock market returns. About 25\% to $40 \%$ of the returns can be predicted based on past profit information. The returns of small sized companies can be more easily predicted; $40 \%$ can be predicted based on past performance. The prediction rate is about $25 \%$ for large sized companies. Therefore, overreactions in price will eventually have mean reversion. De Long, Shleifer, Summers and Waldmann (1990) argue that noise trading will cause overreactions. Therefore, when the asset prices rise or fall too much, it is likely to correct in the other direction. Therefore, the long-term return is often negatively autocorrelated. Moreover, Cutler, Poterba and Summers (1988) find negative autocorrelations in 3 to 5 year stock market returns. The results suggest that price may underreact initially and then gradually correct in the long term. Bremer and Sweeney (1991) examine Fortune 500 companies between July 1962 and December 1986. Stocks whose prices vary by more than $7.5 \%, 10 \%$ and $15 \%$ in one day are all included in the sample. These stocks are followed for 20 days after rising or falling in prices. Their results show that for losers, the returns are $2.84 \%, 3.95 \%$ and $6.18 \%$ five days after. On the other hand, there is no abnormal profit for winners. Therefore, there are significant corrections for losers while no corrections for winners. The degree of correction also increases with the initial price changes. Poterba and Summers (1988) further show that short-term stock prices are positively related in the short term while 3 to 5 year stock returns are negatively autocorrelated in England and in the other 16 countries / regions. 
Lakonishok et al. (1994) use three indicators to further test the contrarian strategy based on NYSE and AMEX listed companies between 1968 and 1990. They find that the stock portfolio with low $\mathrm{P} / \mathrm{E}$ ratio beats the portfolio with high $\mathrm{P} / \mathrm{E}$ ratio. Also, the portfolio with lowest $\mathrm{P} / \mathrm{BV}$ ratio has 5-year average holding return of $19.8 \%$. In contrast, the return of highest $\mathrm{P} / \mathrm{BV}$ ratio is only $9.3 \%$. In addition, during the 25 good performing months of the stock market, the average returns of portfolios with lowest and highest $\mathrm{P} / \mathrm{BV}$ ratios are $14.8 \%$ and $11.4 \%$, respectively. During the 88 bad performing months of the stock market, the portfolio with low $\mathrm{P} / \mathrm{BV}$ ratio still has higher return than the portfolio with high $\mathrm{P} / \mathrm{BV}$ ratio. The results suggest that stocks with low $\mathrm{P} / \mathrm{BV}$ ratio have lower risks. Further, the portfolio with higher $\mathrm{P} / \mathrm{CF}$ ratio has lower 5-year average holding returns (9.1\%) than the portfolio with lower $\mathrm{P} / \mathrm{CF}$ ratio (20.1\%). Hackel et al. (1996) also study the relationship between P/CF and investment returns for NYSE listed companies between 1980 and 1994. After classifying the sample into five groups based on $\mathrm{P} / \mathrm{E}$ ratio, they find that the average yearly return of S\&P 500 companies is $19.2 \%$ for the portfolio with lowest $\mathrm{P} / \mathrm{CF}$ ratio, which is higher than the average return of 4.1\%. The investigation by Shiller (2000) shows that on average, investors believe that stock markets will rise again after falling. The law of small numbers suggests that investors may accidentally sell profitable stocks when selling stocks. Therefore, we are able to observe disposition effect. Genesove and Mayer (2001) also find disposition effect in housing market. They find that Boston housing owners have higher selling prices for houses whose prices are falling than houses whose prices are not falling. In fact, the selling price is $25 \%-35 \%$ higher. The evidence again shows that contrarian strategy is workable.

In contract, in the real market, there exists a group of irrational traders who adopt positive feedback strategy. The positive feedback strategy can lead to herding behavior, extrapolation expectation and technical analyses. The herding behavior arises because of incomplete information and uncertainty in the market. By mimicking other's behavior, the investor can save the cost of gathering information and have less aversion if making losses. As herding behavior involves many investors, it has strong impacts on the stability and efficiency of the financial market. Lakonishok et al. (1992) analyze 769 US stock funds between 1985 and 1989 and find that fund managers will observe the trading behavior of other fund managers when trading small companies' stocks. This is because small companies have less publicly available information. Froot et al. (1994) also observe herding behavior among institutional investors in the face of new external information. The reason is that institutional investors typically utilize similar data sources, economic models, investment portfolios and hedging strategies. Werners (1999) examines all US mutual funds between 1975 and 1994 and find evidence of herding behavior in mutual funds. In fact, stocks that have been commonly purchased by mutual funds have better same-period and lag-period returns than those that have been commonly sold by mutual funds. Werners (1999) believes that the herd trading behavior of mutual funds is rational and can help speed up the reflection of information in stock prices and the stability of the market. Based on the NYSE listed companies between 1926 and 1982, DeBondt et al. (1985) find that companies with better performance in the previous year perform better in the year after. Jegadeesh and Timan (1993) find evidence of momentum effect in the market in the short and medium terms. That is, stocks whose prices are currently rising or have already risen are likely to remain so in the following 18 months, and vice versa. Investors who have bought in good performing stocks and sold bad performing stocks at the same time are likely to gain 9.29\% abnormal returns in the following 3 to 12 months. Following Jegadeesh and Timan's (1993) methods, Rouwenhourst (1998) also finds momentum effects in twelve European countries' stock markets and the strategy can contribute to $1.16 \%$ abnormal returns every month.

Another argument on efficient market is on the predictability of financial asset returns based on technical analyses. If the technical analysis is workable, then the stock market is only weak- 
form efficient. Lo and MacKinlay $(1988,1999)$ show that random effects do not exist in US stock's weekly index. Past price information can in some degree be used to predict future returns. This is because all factors have reflected in current market prices and the prices will move with the trend. The validity of these results is affected by data-snooping bias. When the data is repeatedly used, the satisfactory results may be due to luck rather than the predictability of the model. White (2000) proposes a "reality check bootstrap methodology" to enhance the empirical check of technical trading. Brock, Lakonishok and LeBaron (1992) adopt 26 different technical trading rules in Dow Jones Industrial Index in 1990 and find that technical trading leads to higher returns than the base model of holding cash. However, datasnooping bias exists in technical trading rules when search for parameters. This study follows the testing method in Lan et al. $(2014,2015)$ and uses econometrics models and optimized program trading to conduct a two-stage test. The aim is to find a stable investment strategy. The hypothesis to be tested is as follows:

The price spread of TAIEX futures and MSCI Taiwan Index Futures has a mean reversion property. In other words, when the technical analysis shows the two indices diverge, then the contrarian strategy can lead to higher profits.

\section{Event Study Model and Estimation Methods}

\section{RESEARCH METHODS}

This study uses the event studies to test the effect of QE on investors' behavior by examining the price changes in Taiwan 50 ETF. ${ }^{1}$ Based on the data obtained from Taiwan Economic Journal (TEJ) database, we use GARCH model to test the abnormal returns on the announcement day.

The event study model is summarised as follows:

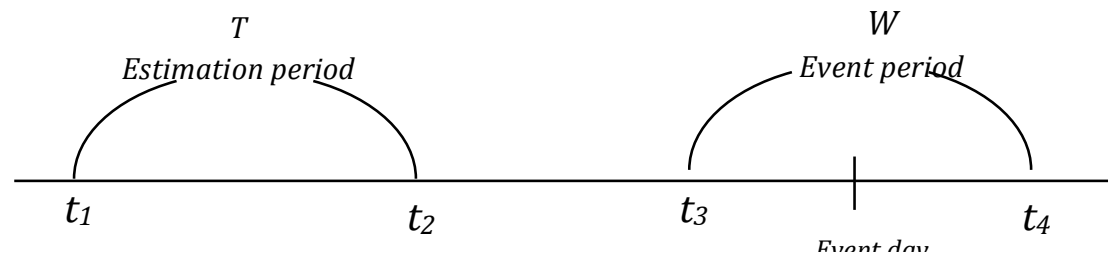

$\mathrm{t}$ : time $\mathrm{T}$ : Estimation period $\mathrm{W}$ : Event period

Estimated return based on the market model is as follows:

$R_{t}=\alpha+\beta R_{m t}+\varepsilon_{t}$

where $\mathrm{R}_{\mathrm{t}}$ : Stock return at time $\mathrm{t}$; $\mathrm{R}_{m t}$ : Market return on day $\mathrm{t}$

$\hat{\varepsilon}_{t} \mid \boldsymbol{\Omega}_{t-1} \sim N\left(0, h_{t}\right)$

Expected value of the error term, $\varepsilon_{t}$, is zero.

$h_{t}=d_{0}+d_{1} \varepsilon_{t-1}^{2}+d_{2} h_{t-1}$

Abnormal return (AR) during the event period is:

${ }^{1}$ As the futures' prices lead the spot market's prices, Taiwan 50 ETF, a spot market security, is used a substitute variable for Taiwan index futures. 
$A R_{t}=R_{t}-\hat{R}_{t}$

where $R_{t}=\ln P_{t}-\ln P_{t-1} ; \mathrm{P}$ is the stock price.

Cumulative abnormal return (CAR) can be calculated as follows:

$C A R=\sum_{t=t_{3}}^{t_{4}} A R_{t}$

To take into account of the trading restriction after the announcement, this study uses 600 days before and after the day with the lowest US Dollar Index (2011.5.2) as the event period. That is, a total of 1200 days are used to test if AR and CAR are significantly different from zero. The estimation period includes 1000 days which are based on the weighted index of listed companies.

\section{VAR Model and Estimation Methods}

To ensure that all variables in the model have causality relationships and to avoid the identification problem in simultaneous structural equations, Sim (1980) applies the vector autoregression model in econometrics. All variables in the model are lagged variables of itself and other variables. When the single variable autoregression is extended as multi-variable vector autoregression, we do not need to worry about how to set exogenous variables. All variables are endogenous and can be used to predict a relevant time series system and the dynamic impact on this system by random noises. In this study, the three variables in the model are $y_{1 t}, y_{2 t}, y_{3 t}$ Variable in time $t$ is formed by the variable in the prior time $k$ and the error term. That is, taking VAR(1) (i.e., $\mathrm{k}=1$ ) as an example:

$$
\begin{aligned}
& \mathrm{y}_{1 \mathrm{t}}=\mathrm{m}_{1}+\mathrm{a}_{11} \mathrm{y}_{1, \mathrm{t}-1}+\mathrm{a}_{12} \mathrm{y}_{2, \mathrm{t}-1}+\mathrm{a}_{13} \mathrm{y}_{3, \mathrm{t}-\mathrm{1}}+\varepsilon_{1 \mathrm{t}} \\
& \mathrm{y}_{2 \mathrm{t}}=\mathrm{m}_{2}+\mathrm{a}_{21} \mathrm{y}_{1, \mathrm{t}-1}+\mathrm{a}_{22} \mathrm{y}_{2, \mathrm{t}-1}+\mathrm{a}_{23} \mathrm{y}_{3, \mathrm{t}-1}+\varepsilon_{2 \mathrm{t}} \\
& \mathrm{y}_{3 \mathrm{t}}=\mathrm{m}_{3}+\mathrm{a}_{31} \mathrm{y}_{1, \mathrm{t}-1}+\mathrm{a}_{32} \mathrm{y}_{2, \mathrm{t}-1}+\mathrm{a}_{33} \mathrm{y}_{3, \mathrm{t}-1}+\varepsilon_{3 \mathrm{t}}
\end{aligned}
$$

where $\mathrm{E}\left(\varepsilon_{\mathrm{t}}\right)=0, \forall \mathrm{t}, \mathrm{E}\left(\varepsilon_{\mathrm{t}} \varepsilon_{\mathrm{s}}^{\prime}\right)=\left\{\begin{array}{l}\Omega, \mathrm{s}=\mathrm{t} \\ 0, \mathrm{~s} \neq \mathrm{t}\end{array}, \Omega=\mathrm{E}\left(\varepsilon_{\mathrm{t}} \varepsilon_{\mathrm{t}}^{\prime}\right)\right.$

The error term $\varepsilon_{\mathrm{t}}$ is white noise; $\mathrm{m}$ is the constant, a is the coefficient and $\Omega$ is a positive definite variable and a covariance matrix. That is, the error terms $\varepsilon_{\mathrm{t}}$ can be correlated at the same period but cannot be correlated with its lagged period or the variables at the right-hand side of the equation. From here, the test on causality relationship is developed.

\section{Granger Causality Model and Estimation Methods}

As the economic theory on the relationship between the price spread (TXFDIFF) of TAIEX futures and MSCI Taiwan Index Futures and the TAIEX futures (DTXF) is yet unclear, the causality test of Granger $(1969,1988)$ can be used to clarify such relationship. Specifically, the model can test if the coefficients of current $y$ series and the past values of $x$ series have causal relationship. That is, whether the past values of $\mathrm{x}$ can explain the present values of $\mathrm{y}$. The model tests if adding a lagged value of $x$ can increase the degree of explanation. If the correlation coefficient of $\mathrm{x}$ and $\mathrm{y}$ are statistically significant, we can then conclude that $\mathrm{y}$ is Granger caused by $\mathrm{x}$.

If the series do not have the property of unit root, the causality relationship can be tested using the following model:

$$
\begin{aligned}
& Y_{t 1}=\delta_{0}+\sum_{i=1}^{m} \delta_{i} Y_{t 1-i}+\sum_{i=1}^{m} \gamma_{i} Y_{t 2-i}+\varepsilon_{t} \\
& Y_{t 2}=\lambda_{0}+\sum_{i=1}^{n} \lambda_{i} Y_{t 2-i}+\sum_{i=1}^{n} \omega_{i} Y_{t 1-i}+v_{t}
\end{aligned}
$$


where $\varepsilon_{t}$ and $v_{t}$ in Equation (2) are white noise error terms. $m$ and $n$ are the optimal lag periods based on SC's minimum value. The null hypothesis is $\gamma=0, \omega=0$. If $\gamma \neq 0, \omega=0$, then $\mathrm{Y}_{2}$ has a Granger lead on $Y_{1}$, and vice versa $\left(Y_{1}\right.$ has a Granger lead on $\left.Y_{2}\right)$. If both ${ }^{\gamma}$ and ${ }^{\omega}$ are not equal to 0 , a bidirectional causality relationship exists.

\section{Experimental Design and Estimation Methods}

This study incorporates three models in the experiment. Model 1 is the contrarian trading model with only one set of data (data1) (i.e., TAIEX futures). Model 1 is purely based on RSI oscillators. That is, when there is no long position (or there is a short position), the investor will buy when $\mathrm{RSI}<35$. When there is no short position (or there is a long position), the investor will sell when RSI $>65$.

Model 2 is a mean reversion model based on Williams' (1999) program trading design. To increase the trading performance, apart from data1, another set of data (i.e., the price spread of TAIEX futures and MSCI Taiwan Index Futures) is used as a filter. To ensure the fairness in evaluation, the models are estimated based on the following trading strategies. That is, apart from data1, another set of data (i.e., the price spread of TAIEX futures and MSCI Taiwan Index Futures) is included as a filter. The model in this study is estimated based on the following trading strategies. Specifically, apart from data1 (i.e., price of TAIEX futures), the price spread (TXFDIFF) of data2 (i.e., TAIEX futures, denoted as TXF) and data3 (i.e., MSCI Taiwan Index Futures, denoted as SGX) is included as an indicator. The technical analysis of diversion trading strategy ${ }^{2}$ in program trading is carried out as follows:

1. The index uses RSI oscillators. Data1 is the price of TAIEX futures.

2. Calculate the price spread of two futures as the indicator (i.e., the price of data2 (TXF) subtract the price of data3 (SGX) times 100).

3. When at least nine $\mathrm{K}$ bars are above 70 (or below 30) and the values of RSI are twice above 70 (or below 30), this can be included. In addition, when the closing price obtains a new high (or low) within nine K bars but the RSI does not, the strategy is to sell (or buy) at this low (or high) point in the future.

Model 3 is a momentum model. It is a trading strategy (Model 2) that is based on Kestner moving average system and uses the closing price and the breakthrough point in 20-day and 80 -day moving average. There are two conditions in Kestner moving average system. First, buy if today's closing price is higher than the high point of 20-day (80-day) moving average and the 20-day (80-day) moving average is higher than yesterday's closing price. Second, sell if today's closing price is lower than the low point of 20-day (80-day) moving average and the 20-day (80-day) moving average is lower than yesterday's closing price. To ensure the consistency in comparison with Model 1, the former allows the simulation period to increase by $10 \%$ in today and 100-day moving average and the latter allows the simulation period to increase by 10-30 days and 60-80 days for 20-day and 80-day moving average. The optimal number of days for moving average is found out by the program.

This study uses MultiCharts program trading to conduct backtesting in the first stage (2011.5.2 2013.7.13). The optimal coefficient that occurs when we have at least nine K bars

2 When the price reaches a new high (or a new low) but the index does not. 
and RSI is above 70 (or below 30) is brought into the second stage (2011.5.2 2016.02.03) and the third stage (2011.5.2 2017.01.20) to estimate the Taiwan futures market. This way, we can see if technical analysis can enhance trading profits by incorporating the price spread between two index futures. In addition, to ensure the fairness in evaluation, the simulation period is expanded for the second set of data (2010.6.12 2016.2.21) and the third stage (2010.6.12 2017.01.20).

\section{DATA}

This study examines whether the trading profits can be increased by incorporating the price spread of TAIEX futures and MSCI Taiwan Index Futures as a variable. The daily data used include the prices of TAIEX futures and MSCI Taiwan Index Futures that are obtained from XQ database. To ensure that benchmarks are comparable, the data are divided into two groups. One group has a shorter learning period of 27 months. The other group has a longer learning period of 36 months. For the experimental design, the data period for the first stage covers from a history low on 2 May 2011 to a short-term period high on 13 July 2013 (i.e., 547 sample points). The second stage covers from 2 May 2011 to 21 February 2016 (i.e., 1315 sample points) and the third stage covers from 21 February 2016 to 20 January 2017. The experimental method involves using the optimized simulated parameters obtained from the first stage in the second and third stages.

The second group is based on cycle. The first stage covers from a high on 12 June 2010 to the next high on 13 July 2013 (i.e., 641 sample points). The second stage covers from 12 June 2010 to 21 February 2016 (i.e., 1409 sample points), and the third stage covers from 21 February 2016 to 20 January 2017. Similarly, the optimized simulated parameters obtained from the first stage are to be used in the second and third stages. All data mentioned above are calculated at level except for those original data that is I(1). These need to be differentiated and represented by D. Also, the transaction cost in each model is about $\$ 1000$.

\section{Granger Causality Test of Taiwan 50 ETF's CAR \\ EMPIRICAL RESULTS}

To ensure the suitability of TAIEX futures and MSCI Taiwan Index Futures as variables, it is important to first analyze their relationships. Hence, we use the event study method and show that under QE, MSCI Taiwan Index Futures is the Granger cause of TAIEX futures. The TAIEX futures is the Granger cause of average CAR of the top 50 companies with largest weighting in the index (i.e., Taiwan 50 ETF). The following sections describe the analytical steps that this study has taken.

\section{AVERAGE CAR OF TAIWAN 50 ETF (0050)}

The QE in the US started in November 2008 and ended in October 2014, lasting for six years. This study chooses 2 May 2011 as the announcement day. On this day, the US Dollar Index reached a history low. The futures market has the price discovery function of the spot market. Institutional investors often use TAIEX futures and MSCI Taiwan Index Futures as hedging and arbitrage tools and choose Taiwan 50 ETF, which comprises Taiwan's top 50 weighted companies, as the investment target. Therefore, the average CAR of Taiwan 50 ETF can reflect investors' sentiment to QE. Figure 1 shows the AR/CAR of GARCH model. The figure suggests that after $\mathrm{QE}$, the average CARs are mostly negative (-6\% -8\%). Although there is a temporary bounce back in 2009, it continues to fall afterwards. In 2014, the average CAR has reached $10 \%$. The results reflect the harsh economy at that time, which consequently affects the price of Taiwan 50 ETF. 


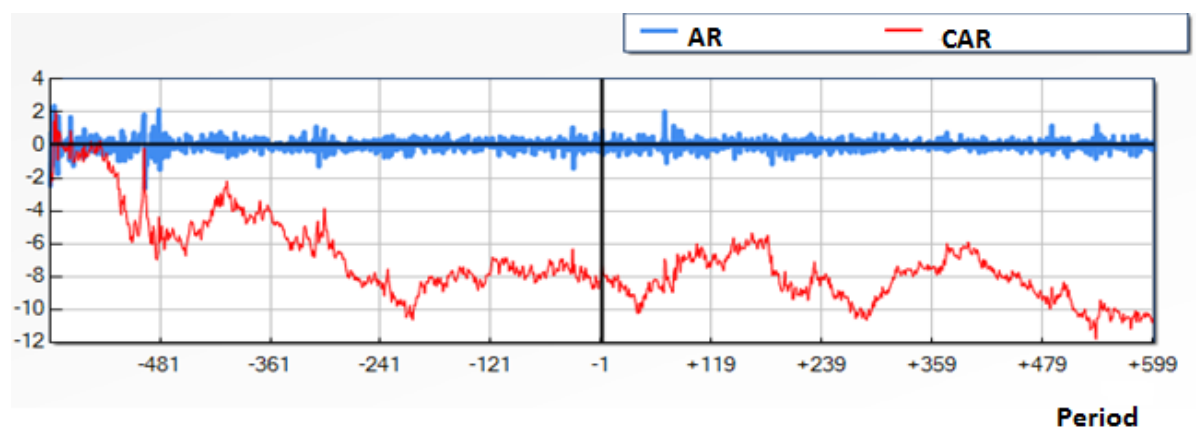

Figure 1 AR and CAR of Taiwan 50 ETF around QE announcement

\section{Unit Root Test of Sample Data}

To ensure the validity of empirical results, before testing the causal relationship between variables, we need to make sure that the time series of variables have the same level. Hence, ADF unit root test is carried out to ensure that the average CAR of Taiwan 50 ETF, TAIEX futures, MSCI Taiwan Index Futures and the price spread are stationary. Based on the test of lagged period with minimum SC, the data at the original level mostly cannot reject the null hypothesis. The results suggest that these variables are not stationary and are characterized by fat-tails. The time series also have autocorrelations. Hence, after taking the first difference, the series become stationary and meet the condition of cointegration. Therefore, we can proceed with Granger causality test.

Table 1 Unit root test of Granger model's variables

\begin{tabular}{|l|c|c|c|}
\hline Variables / Model & Intercept (C) & $\begin{array}{c}\text { Trend (T) and intercept } \\
(\mathrm{C})\end{array}$ & $\begin{array}{c}\text { No trend (T) and } \\
\text { intercept (C) }\end{array}$ \\
\hline CAR50 & $-2.9473(1)^{* * *}$ & $-2.9009(0)$ & $-0.3319(0)$ \\
\hline D(CAR50) & $-42.7227(0)^{* * *}$ & $-42.7144(0)^{* * *}$ & $-42.7294(0)^{* * *}$ \\
\hline TXA & $-3.1656(1)^{* *}$ & $-2.8452(0)$ & $0.7853(0)$ \\
\hline D(TXA) & $-32.6900(0)^{* * *}$ & $-32.7283(0)^{* * *}$ & $-32.6643(0)^{* * *}$ \\
\hline MSCI & $-2.4929(0)$ & $-2.3450(0)$ & $0.6461(0)$ \\
\hline D(MSCI) & $-33.8697(0)^{* * *}$ & $-33.8718(0)^{* * *}$ & $-33.8610(0)^{* * *}$ \\
\hline
\end{tabular}

Note: According to Mackinnon (1991), *,**, and *** represent significance at $10 \%, 5 \%$ and $1 \%$ level, respectively. The $\mathrm{C}, \mathrm{T}$, and $\mathrm{L}$ in the model represent the intercept, trend and lagging period. TXA, MSCI and CAR50 represent the price of TAIEX futures, the price of MSCI Taiwan Index Futures and the average CAR of Taiwan 50 ETF. D represents differentiated data.

\section{Estimation Results of VAR Model}

This section examines the causality relationship between the average CAR of Taiwan 50 ETF, TAIEX futures and MSCI Taiwan Index Futures using the VAR model. The results show that in the short term, TAIEX futures lead Taiwan 50 ETF for one period. MSCI Taiwan Index Futures lead TAIEX futures for one period as well (as shown in Table 2). 
Table 2 Estimation results of VAR model

\begin{tabular}{lccc}
\hline \hline & D(CAR50) & D(TXA) & D(MSCI) \\
\hline \hline D(CAR50(-1) & -0.207544 & 1.076611 & 0.031691 \\
& {$[0.02794)$} & {$[6.90077)$} & {$[0.25418)$} \\
D(TXA(-1)) & {$[-7.42728]$} & {$[0.15601]$} & {$[0.12468]$} \\
& -0.000658 & 0.060072 & -0.000700 \\
& {$[0.00012)$} & {$[0.02889)$} & {$[0.00106)$} \\
D(MSCI(-1)) & {$[-5.62500]$} & {$[2.07951]$} & {$[-0.65821]$} \\
& -0.001199 & -1.371769 & 0.020850 \\
C & {$[0.00318)$} & {$[0.78569)$} & $(0.02894)$ \\
& {$[-0.37690]$} & {$[-1.74593]$} & {$[0.72048]$} \\
& -0.004614 & 3.194283 & 0.090891 \\
& {$[0.01093)$} & {$[2.70038)$} & {$[0.09946)$} \\
\hline \hline & {$[-0.42200]$} & {$[1.18290]$} & {$[0.91382]$} \\
\hline \hline Determinant resid covariance (dof adj.) & 14656.54 & \\
Log likelihood & & -10821.54 & \\
Akaike information criterion & 18.11629 & \\
Schwarz criterion & 18.16733 & \\
\hline \hline
\end{tabular}

\section{Granger Causality Test}

This section examines the Granger causality relationship between the average CAR of Taiwan 50 ETF, TAIEX futures and MSCI Taiwan Index Futures. The results show that when lagging one period, the TAIEX futures lead the average CAR of Taiwan 50 ETF. MSCI Taiwan Index Futures also lead TAIEX futures (as shown in Table 3). In other words, institutional investors do indeed attempt to influence TAIEX futures through MSCI Taiwan Index Futures, which consequently have an influence on Taiwan stock markets (or the Taiwan 50 ETF). Therefore, in the next section, the price spread between TAIEX futures and MSCI Taiwan Index Futures is included in the model to conduct backtesting using program trading. This can help us understand the effect on trading performance. 
Table 3 Granger causality test

\begin{tabular}{|c|c|c|c|}
\hline \multicolumn{4}{|c|}{ Dependent variable: D(CAR50) } \\
\hline Excluded & Chi-sq & df & Prob. \\
\hline D(TXA) & 31.64061 & 1 & 0.0000 \\
\hline D(MSCI) & 0.142054 & 1 & 0.7062 \\
\hline All & 31.83514 & 2 & 0.0000 \\
\hline \multicolumn{4}{|c|}{ Dependent variable: D(TXA) } \\
\hline Excluded & Chi-sq & df & Prob. \\
\hline D(CAR50) & 0.024340 & 1 & 0.8760 \\
\hline D(MSCI) & 3.048281 & 1 & 0.0808 \\
\hline All & 3.063149 & 2 & 0.2162 \\
\hline \multicolumn{4}{|c|}{ Dependent variable: $\mathrm{D}(\mathrm{MSCI})$} \\
\hline Excluded & Chi-sq & df & Prob. \\
\hline D(CAR50) & 0.015546 & 1 & 0.9008 \\
\hline D(TXA) & 0.433242 & 1 & 0.5104 \\
\hline All & 0.450943 & 2 & 0.7981 \\
\hline
\end{tabular}

\section{Granger Causality Test of TAIEX Futures Trading Model Unit Root Test of Sample Data}

To ensure the validity of results, we need to ensure the stability of variables before testing their causality relationships.

Table 4 Unit root test of Granger model's variables

\begin{tabular}{|l|c|c|c|}
\hline Variables / Model & Intercept (C) & $\begin{array}{c}\text { Trend (T) and intercept } \\
(\mathrm{C})\end{array}$ & $\begin{array}{c}\text { No trend (T) and intercept } \\
(\mathrm{C})\end{array}$ \\
\hline TXF & $-2.3350(0)$ & $-2.3481(0)$ & $0.1208(0)$ \\
\hline $\mathrm{D}(\mathrm{TXF})$ & $-35.8174(0)^{* * *}$ & $-35.8105(0)^{* * *}$ & $-35.8280(0)^{* * *}$ \\
\hline SGX & $-2.2737(0)$ & $-2.4396(0)$ & $-0.1492(0)$ \\
\hline $\mathrm{D}(\mathrm{SGX})$ & $-37.7112(0)^{* * *}$ & $-37.7023(0)^{* * *}$ & $-37.7213(0)^{* * *}$ \\
\hline TXFDIFF & $-2.3417(0)$ & $-2.3512(0)$ & $-0.1180(0)$ \\
\hline D(TXFDIFF) & $-35.1822(0)^{* * *}$ & $-35.8053(0)^{* * *}$ & $-35.8229(0)^{* * *}$ \\
\hline
\end{tabular}

Note: According to Mackinnon (1991), *,**, and *** represent significance at $10 \%, 5 \%$ and $1 \%$ level, respectively. The $\mathrm{C}, \mathrm{T}$, and $\mathrm{L}$ in the model represent the intercept, trend and lagging period. TXF, SGX and TXFDIFF represent the price of TAIEX futures, the price of MSCI Taiwan Index Futures and the price spread. D represents the differentiated data. 
At the original level, the data including TAIEX futures, MSCI Taiwan Index Futures and the price spread cannot mostly reject the null hypothesis based on the test of lagged period with minimum SC. The results suggest that the variables are not stationary. After taking the differentiation, the series become stationary and meet the condition of cointegration. That is, $\mathrm{I}(1)$ is a stationary series and we can proceed with Granger causality test.

\section{Granger Causality Test}

This section examines the Granger causality relationship between the price spread of TAIEX futures, MSCI Taiwan Index Futures (TXFDIFF) and TAIEX futures (DTXF). The results show that when lagging two periods, bidirectional Granger relationship exists (as shown in Table 5). Therefore, the price spread and TAIEX futures are Granger cause of each other. In the next section, these two variables are included in the model to conduct backtesting using program trading. This can help us analyze the effect of price spread on trading performance.

Table 5 The Granger relationship of the price spread and TAIEX futures

\begin{tabular}{llll}
\hline \hline \multicolumn{4}{l}{ Dependent variable: D(TXFDIFF) } \\
\hline \hline Excluded & Chi-sq & df & Prob. \\
\hline \hline D(TXF) & 5.284125 & 2 & 0.0712 \\
\hline \hline All & 5.284125 & 2 & 0.0712 \\
\hline \hline Dependent variable: D(TXF) & \\
\hline \hline Excluded & Chi-sq & df & Prob. \\
\hline \hline D(TXFDIFF) & 4.631901 & 2 & 0.0987 \\
\hline \hline All & 4.631901 & 2 & 0.0987 \\
\hline \hline
\end{tabular}

\section{TAIEX Futures and the Effect of Price Spread on Trading Performance Model 1 (Contrarian Model)}

Using daily data, this section examines the situation in which investors trade based on existing TAIEX futures information and RSI technical analysis. Based on three stages of simulation, in a shorter period (2011.5.2 2013.7.13) the profit in the first stage is $\$ 563,000$. When the optimal parameter from the first stage is utilized in the second and third stages, the profits become $\$ 984,600$ and $1,008,200$, respectively. The increment is as high as $78.8 \%$. Based on three stages of longer periods of learning (2011.5.2 2013.7.13), the profits become $\$ 831,600$ in the first stage, $\$ 916,800$ in the second stage and $\$ 1,088,600$ in the third stage. The increment is a high as $30.9 \%$. In the same period, the TAIEX futures have increased by $14.02 \%$ from 8141 to 9283. In other words, based on the RSI technical analysis, without the price spread information, investors are able to make profits solely based on the past information of TAIEX futures (as shown in Table 6). 
Table 6 Total trading analysis of Model 1 across three stages (daily data)

Unit: dollar

\begin{tabular}{|c|c|c|c|c|c|c|}
\hline \multirow{2}{*}{ Period } & \multicolumn{3}{|c|}{$2010.6 .12 \sim 2013.7 .13 \sim 2016.2 .21$} & \multicolumn{3}{c|}{$2011.5 .2 \sim 2013.7 .13 \sim 2016.2 .21 \sim$} \\
& \multicolumn{3}{|c|}{$\sim 2017.1 .20$} & \multicolumn{3}{c|}{2017.1 .20} \\
\hline Stages & Stage I & Stage II & Stage III & Stage I & Stage II & Stage III \\
\hline Winning Probability & $100 \%(4 / 4$ & $100 \%(5 / 5$ & $100 \%(6 / 6$ & $100 \%(3 / 3$ & $100 \%(5 / 5$ & $100 \%(6 / 6$ \\
(Trading No. / Success No.) & ) & ) & ) & ) & ) & ) \\
\hline Net profits & 831,600 & 916,800 & $1,088,600$ & 563,600 & 984,600 & $1,008,200$ \\
\hline
\end{tabular}

Next, using hourly data (i.e., the intraday data), we investigate the situation in which investors trade based on existing TAIEX futures information and RSI technical analysis. Based on three stages of simulation, in a shorter period the profit in the first stage is $\$ 525,200$. When the optimal parameter from the first stage is utilized in the second and third stages, the profits reduce to $\$ 10,800$ and 260,600 , respectively. The decline reaches as large as $-50.38 \%$. Based on three stages of longer periods of learning, the profits become $\$ 479,600$ in the first stage, $\$ 259,000$ in the second stage and $\$ 219,800$ in the third stage. The decline is as large as $54.17 \%$. Therefore, with only the past information of TAIEX futures and without the price spread information, investors may not gain from trading (as shown in Table 7).

Table 7 Total trading analysis of Model 1 across three stages (hourly data)

Unit: dollar

\begin{tabular}{|c|c|c|c|c|c|c|}
\hline \multirow{2}{*}{$\begin{array}{l}\text { Period } \\
\text { Stages }\end{array}$} & \multicolumn{3}{|c|}{$\begin{array}{c}2010.6 .12 \sim 2013.7 .13 \sim 2016.2 .2 \\
1 \sim 2017.1 .20\end{array}$} & \multicolumn{3}{|c|}{$\begin{array}{c}2011.5 .2 \sim 2013.7 .13 \sim 2016.2 .21 \\
\sim \\
2017.1 .20 \\
\end{array}$} \\
\hline & Stage I & Stage II & Stage III & Stage I & Stage II & Stage III \\
\hline $\begin{array}{l}\text { Winning Probability } \\
\text { (Trading No. / Success } \\
\text { No.) }\end{array}$ & $\begin{array}{c}66 \%(42 / \\
28)\end{array}$ & $\begin{array}{c}59 \%(72 / \\
43)\end{array}$ & $\begin{array}{c}60 \%(84 / \\
51)\end{array}$ & $\begin{array}{c}75 \%(24 / \\
18)\end{array}$ & $\begin{array}{c}57 \%(42 / \\
24)\end{array}$ & $\begin{array}{c}60 \%(56 / \\
34)\end{array}$ \\
\hline Net profits & 479,600 & 259,000 & 219,800 & 525,200 & 10,800 & 260,600 \\
\hline
\end{tabular}

\section{Model 2 (Mean Reversion Model)}

This section tests Model 2 by including the price spread information of TAIEX futures and MSCI Taiwan Index Futures. The results show that the profit in the first stage is $\$ 700,000$. When the optimal parameter from the first stage is used in the second and third stages, the profits become $\$ 983,800$ and 827,600 , respectively. The increment is as high as $18.22 \%$. Based on three stages of longer periods of learning, the profits become $\$ 1,111,400$ in the first stage, $\$ 1,395,000$ in the second stage and $\$ 1,238,800$ in the third stage. The results suggest that including the price spread information and using the property of mean reversion, although the profits slightly decrease in 2017, this trading strategy can still lead to profits, which have increased by $11.46 \%$. Since investors can profit based on past information, the results suggest that the Taiwan futures market is not efficient (as shown in Table 8) 
Table 8 Total trading analysis of Model 2 across three stages (daily data)

Unit: Dollar

\begin{tabular}{|c|c|c|c|c|c|c|}
\hline Period & \multicolumn{3}{|c|}{$\begin{array}{c}2010.6 .12 \sim 2013.7 .13 \sim 2016.2 .2 \\
1 \sim 2017.1 .20\end{array}$} & \multicolumn{3}{|c|}{$\begin{array}{c}2011.5 .2 \sim 2013.7 .13 \sim 2016.2 .21 \\
\sim \\
2017.1 .20 \\
\end{array}$} \\
\hline Stages & Stage I & Stage II & Stage III & Stage I & Stage II & Stage III \\
\hline $\begin{array}{l}\text { Winning Probability } \\
\text { (Trading No. / Success } \\
\text { No.) }\end{array}$ & $\begin{array}{c}81 \%(11 / \\
9)\end{array}$ & $\begin{array}{c}84 \%(13 / \\
11)\end{array}$ & $\begin{array}{l}73 \%(15 / \\
11)\end{array}$ & $\begin{array}{c}100 \%(7 / \\
7)\end{array}$ & $\begin{array}{c}100 \%(9 / \\
9)\end{array}$ & $\begin{array}{c}81 \%(11 / \\
9)\end{array}$ \\
\hline Net profits & $1,111,400$ & $1,395,000$ & $1,238,800$ & 700,000 & 983,800 & 827,600 \\
\hline
\end{tabular}

Next, using hourly data (i.e., the intraday data), Model 2 shows that in a shorter learning period, the profit in the first stage is $\$ 510,200$. When the optimal parameter from the first stage is used in the second and third stage, the profits in the second and third stages are the same and increase to $\$ 987,000$; that is, an increase of $93.45 \%$. Based on three stages of longer periods of learning, the profits become $\$ 466,000$ in the first stage, $\$ 663,200$ in the second stage and $\$ 590,600$ in the third stage. The increase is a large as $24.24 \%$. Therefore, by incorporating the price spread information, this trading strategy can lead to profits (as shown in Table 9).

Table 9 Total trading analysis of Model 2 across three stages (hourly data) Unit: Dollar

\begin{tabular}{|c|c|c|c|c|c|c|}
\hline \multirow{2}{*}{ Period } & \multicolumn{3}{|c|}{$\begin{array}{c}2010.6 .12 \sim 2013.7 .13 \sim 2016.2 .2 \\
1 \sim 2017.1 .20\end{array}$} & \multicolumn{3}{c|}{$\begin{array}{c}2011.5 .2 ~ 2013.7 .13 \sim 2016.2 .21 \\
\text { 2017.20 }\end{array}$} \\
\hline Stages & Stage I & Stage II & Stage III & Stage I & Stage II & Stage III \\
\hline $\begin{array}{c}\text { Winning Probability } \\
\text { (Trading No. / Success }\end{array}$ & $\begin{array}{c}50 \%(80 / \\
40)\end{array}$ & $\begin{array}{c}57 \%(137 \\
/ 73)\end{array}$ & $\begin{array}{c}50 \%(160 \\
/ 80)\end{array}$ & $\begin{array}{c}46 \%(15 / \\
7)\end{array}$ & $\begin{array}{c}56 \%(23 / \\
16)\end{array}$ & $\begin{array}{c}56 \%(23 / \\
16)\end{array}$ \\
\hline No.) & 466,000 & 663,200 & 579,600 & 510,200 & 987,000 & 987,000 \\
\hline
\end{tabular}

\section{Model 3 (Momentum Model)}

Using daily data for Model 3, in a shorter learning period the first stage shows a loss of $\$ 98,400$. As the optimal parameter is not profitable in the first stage, we do not need to proceed with the second and third stages of simulation. In a longer learning period, the first stage also leads to a loss of $\$-280,400$. As a result, we do not proceed with the second and third stages of simulations. Therefore, the results show that the momentum strategy based on daily data of TAIEX futures is not profitable (as shown in Table 10).

Table 10 Total trading analysis of Model 3 across three stages (daily data)

Unit: dollar

\begin{tabular}{|c|c|c|c|c|c|c|}
\hline \multirow{2}{*}{ Period } & \multicolumn{2}{|c|}{$\begin{array}{r}2010.6 .12 \sim 2013.7 .13 \sim 2016.2 .2 \\
1 \sim 2017.1 .20\end{array}$} & \multicolumn{3}{c|}{ 2011.5.2 2013.7.13 2016.2.21 } \\
\hline $\begin{array}{c}\text { Stages } \\
\text { Winning Probability } \\
\begin{array}{c}\text { Trading No. / Success } \\
\text { No.) }\end{array}\end{array}$ & $0 \%(2 / 0)$ & - & - & $0 \%(2 / 0)$ & - & - \\
\hline Net profits & $-280,400$ & - & - & $-98,400$ & - & - \\
\hline
\end{tabular}


Using hourly data (i.e., the intraday data), Model 3 shows that in a shorter learning period, the profit in the first stage is $\$ 532,400$. When the optimal parameter from the first stage is applied in the second and third stages, the profits reduce to $\$ 437,600$ and 1,800 , respectively. The decline is as large as $-99.58 \%$. As for the three stages of longer periods of learning, the profits become $\$ 661,400$ in the first stage, $\$ 566,600$ in the second stage and $\$ 130,800$ in the third stage. The decline is as large as $-80.22 \%$. In other words, momentum strategy does not to lead to trading profits (as shown in Table 11).

Table 11 Total trading analysis of Model 3 across three stages (hourly data)

Unit: dollar

\begin{tabular}{|c|c|c|c|c|c|c|}
\hline Period & \multicolumn{3}{|c|}{$\begin{array}{c}2010.6 .12 \sim 2013.7 .13 \sim 2016.2 .2 \\
1 \sim 2017.1 .20\end{array}$} & \multicolumn{3}{|c|}{$\begin{array}{c}2011.5 .2 \sim 2013.7 .13 \sim 2016.2 .21 \\
\sim \\
2017.1 .20 \\
\end{array}$} \\
\hline Stages & Stage I & Stage II & Stage III & Stage I & Stage II & Stage III \\
\hline $\begin{array}{l}\text { Winning Probability } \\
\text { (Trading No. / Success } \\
\text { No.) }\end{array}$ & $\begin{array}{c}38 \%(52 / 20 \\
)\end{array}$ & $\begin{array}{c}33 \%(113 / 3 \\
8)\end{array}$ & $\begin{array}{c}33 \%(132 / 8 \\
8)\end{array}$ & $\begin{array}{c}38 \%(36 / 14 \\
)\end{array}$ & $\begin{array}{c}32 \%(97 / 32 \\
)\end{array}$ & $\begin{array}{c}38 \%(118 / 3 \\
9)\end{array}$ \\
\hline Net profits & 661,400 & 566,600 & 130,800 & 532,400 & 437,600 & 1,800 \\
\hline
\end{tabular}

\section{CONCLUSIONS AND RECOMMENDATIONS}

After the financial crisis, the US Federal Reserve adopted quantitative easing monetary policy in an attempt to boost the US economy. After 2015, the US job market stabilized and the Fed ended the QE and started raising interest rate. The hot money started flew out of emerging markets and brought tremendous shocks in financial markets. The aim of this study is to show that institutional investors affect TAIEX futures through MSCI Taiwan Index Futures, which consequently affect Taiwan 50 ETF. This study incorporates the price spread of TAIEX futures and MSCI Taiwan Index Futures in the models to conduct backtesting using program trading. The results can help us answer the question: whether the mean reversion model is better than the contrarian model and the momentum model.

The results show that for the mean reversion model (based on daily data), incorporating the price spread of TAIEX futures and MSCI Taiwan Index Futures in a shorter learning period lead to profits across three stages of simulations. The profits increase from $\$ 700,000$ in the first stage to $\$ 983,800$ and $\$ 827,600$. For the longer learning period, the profits increase from $\$ 1,111,400$ in the first stage to $\$ 1,395,00$ and $\$ 1,238,800$ in the second and third stages, respectively. The increment in profits is even higher when intraday data is used. Therefore, the mean reversion model has higher profits and stability than contrarian and momentum models. The evidence suggests that incorporating the price spread information and utilizing the mean reversion property of behavioral finance can enhance trading performance. Due to the space and time limit, future research can use other futures data in Taiwan to conduct optimal backtesting and run the simulations.

\section{References}

Barberis, N., A. Shleifer, and R.W. Vishny (1998). “A model of Investor Sentiment”, Journal of Financial Economics, 49, 307-343.

Bremer, M. A., and R. J. Sweeney (1991). “The Information Content of Extreme Negative Rates of Return”, Journal of Finance, March. 
Bremer, M. A., and R. J. Sweeney (1988). “The Information Content of Extreme Negative Rates of Return”, Working Paper, Claremount McKenna College, February.

Brock, W., J. Lakonishok, and B. LeBaron(1992). “Simple Technical Trading Rules and the Stochastic Properties of Stock Returns", Journal of Finance, 47, 1731-1746.

Brown, K. C., and W. Van Harlow (1988). "Market Overreaction: Magnitude and Intensity”, Journal of Portfolio Management, Winter, 6-13.

Cutler, D. M., J. M. Poterba and L. H. Summers (1991). “Speculative Dynamics”, Review of Economic Studies, 58(3), 529-546.

De Bondt, W. F. M., and R. H. Thaler (1985). “Does the Stock Market Overreact?”, Journal of Finance, 40, 793-805.

De Long, J. B., A. Shleifer, L. H. Summers and R. J. Waldmann (1990). "Noise Trader Risk in Financial Markets", Journal of Political Economy, 98, August, 703-738.

Fama, E. F. (1965). “The behavior of stock-market prices”, Journal of Business, 38(1), 34-105.

Fama, E. F. (1970). "Efficient capital markets: A review of theory and empirical work”. Journal of Finance, 25(2), 383-417.

Fama, E. F. and K. R. French (1988). "Dividend Yields and Expected Stock Returns”, Journal of Financial Economics, $22,3-25$.

Froot, K. A., D. S. Scharfstein and J. C. Stein (1993). "Risk management: Coordinating corporate investment and financing policies", Journal of Finance, 48(5), 1629-1658.

Genesove, D. and C. Mayer (2001). "Loss aversion and seller behavior: Evidence from the housing market", Quarterly Journal of Economics, 116, 1233-1260.

Granger, C. W. J. (1969). "Investigating Causal Relations by Econometric Model and Cross-Spectral Methods", Econometrica, 37, 24-36.

Granger, C. W. J. (1988). “Some Recent Development in the Concept of Causality”, Journal of Econometrics, 39, 199211.

Hackle, K., S. and J. Livnat (1996). Cash Flow and Securities Analysis, 2nd. Irwin, Chicago, Il, 433-444.

Jegadeesh, N. and S. Timan (1993). "Returns to buying winners and selling losers: Implications for stock market efficiency", Journal of Finance, 48, 65-91.

Kestner, L. (2004). Quantitative Trading Strategies, New York: The McGraw-Hill.

Lakonishok, J., A. Shleifer and R. W. Vishny (1992). “The impact of institutional trading on stock prices”, Journal of Financial Economics, 82, 23-43.

Lakonishok, J., A. Shleifer, and R. W. Vishny (1994). “Contrarian investment, extrapolation, and risk”, Journal of Finance, 49(5), 1541-1578.

Lan, Y. W., D. Lin and L. Lin (2014). "How to Invest Safely in Emerging Country during Global Financial Crisis: A Case Study of Taiwan”, Global Journal of Management and Business Research, 14(4), 29-41.

Lan, Y. W., D. Lin and L. Lin (2016). "How Investors Survive in Crony Capitalism: A Case Study of OBI Pharma Inc. in Taiwan", International Journal of Social Science Studies, 4(9), 49-60.

Lo, A. W., and A. C. MacKinlay (1988). "Stock Market Prices do not Follow Random Walks: Evidence from a Simple Specification Test", Review of Financial Studies, 1, 41-66.

Lo, A. W., and A. Craig MacKinlay (1990). "Data-snooping Biases in Tests of Financial Asset Pricing Models”, Review of Financial Studies, 3, 431-467.

Murphy, J. J. (1986). Technical Analysis of Futures Markets, Routledge, New York.

Poterba, J. M., and L. H. Summers (1988). “Mean Reversion in Stock Prices: Evidence and Implications”, Journal of Financial Economics, 22, October, 27-59.

Rouwenhourst, G. (1998). “International momentum strategies”, Journal of Finance, 53, 267-284.

Shiller, R. J. (1979). “The Volatility of Long-Term Interest Rates and Expectations Models of the Term Structure”, Journal of Political Economy, 87, Dec., 1190-1219.

Shiller, R. J. (2000). Irrational Exuberance, New Jersey: Princeton University Press. 
Sims, C.A., J. H. Stock, and M. W. Watson (1990). "Inference in Linear Time Series Models with Some Unit Roots," Econometrica, 40, 161-182.

Wermers, R. (1999). "Mutual fund herding and the impact on stock prices", Journal of Finance, 54(2), 581-622.

Thaler, R. H., (1992). The Winner's Curse: Paradoxes and Anomalies of Economic Life, The Free Press, New York.

White, H. (2000). “A reality Check for Data Snooping”, Econometrica, 68, 1097-1126.

Williams, L. (1999). Long-Term Secrets to Short-Term Trading, John Wiley \& Sons, Inc. 